\title{
Creating students' communities of Inquiry (COI) in online learning using the Moodle Learning Management System
}

\author{
Khetsiwe Eunice Mthethwa-Kunene \\ Institute of Distance Education, University of Eswatini \\ P. Bag 4, Kwaluseni, M201, Eswatini \\ Tel: +26825170284 Email: kekunene@uniswa.sz \\ Talent Rugube (Corresponding author) \\ Institute of Distance Education, University of Eswatini \\ P. Bag 4, Kwaluseni, M201, Eswatini \\ Tel: +26878606220 E-mail: trugube@uniswa.sz \\ Cosmas Maphosa \\ Institute of Distance Education, University of Eswatini \\ P. Bag 4, Kwaluseni, M201, Eswatini \\ Tel: +26825187083 E-mail: cmaphosa@uniswa.sz
}

\begin{abstract}
The issue of promoting high levels of interactivity in online learning is important and topical. There is always a need to provide opportunities for online learners to work with others and feel a sense of belonging. This desktop review paper explores the possibility of creating communities of inquiry using the Moodle learning management system. In this discussion, we review the general use of a learning management system in an institution of higher learning. We discuss the advantages and disadvantages of online learning. The concept community of inquiry is unpacked, with emphasis on the three presences namely the cognitive, social and teaching presences. By drawing on the interactive features of the Moodle LMS, we discuss how the three presences could be promoted. Conclusions and recommendations are drawn from the discussion.
\end{abstract}

Keywords: online learning, interactivity, collaborative learning, digital learning platform, higher education

DOI: $10.7176 / \mathrm{JEP} / 11-30-18$

Publication date:October $31^{\text {st }} 2020$

\section{Introduction}

The utilisation of digital learning management systems for online learning has brought with it calls for increased interactivity. There are criticisms levelled against online learning and one of them is about challenges of student interactivity (Larson, 2002). MacKinnon (2002) also notes that online course instructors work under increased pressure to design and implement online programmes that are comparable if not better than face-to-face programmes in terms of all aspects of the programme such as learning outcomes, course content, teaching and learning activities and assignments. The issue of making opportunities available for students to work collaboratively online as they would do in a face-to-face contact class is very important.

Espasa and Meneses (2010) identify three forms of interactivity in online learning namely student-student, studentinstructor and student-content interaction. Of importance in communities of inquiry is student-student interaction, which allows learners to work collaboratively with their peers. As observed by Salmon (2013) when learners work together they cease to rely on the course instructor but are provided with opportunities to co-construct and share knowledge. Through peer interaction, learners create and share meaning of the knowledge in course content. In the process of co-construction and sharing of knowledge, communities of practice are built. To this end, the course instructors would need to enhance collaborative learning by leveraging on the features of a learning management system. 
There are two modern learning theories which underpin the significance of collaboration in online learning namely the online collaborative learning theory and connectivism. According to Harasim (2017) the online collaborative learning theory is rooted in social constructivism. It assumes that learners discuss and work together in the learning. It values the process of working together in a technology-mediated environment. Harasim (2017) identifies three stages in the theories which are idea generation, idea organisation and intellectual convergence. Features of a learning management system should be utilised to allow learners to generate and organise ideas collaboratively. The Connectivism theory by Siemens (2005) advances the view that learning is a process of creating networks. The learner creates networks with other learners by working with them online (Boitshwarelo ,2011, p.162).

The central idea in connectivism is that of learners connecting to a learning community and benefiting from it while also feeding it with information. The learning community is a group of people learning together through continuous dialogue because of their similar interests

The idea of the learning community raised above is the same with the communities of practice, which provide the learners with great opportunity for creating networks. Learners work together and mutually benefit in knowledge sharing.

Siemens (2005) further notes that in connectivism, learning resides outside the learner. This shows that the learner has to utilise online learning and social media tools to learn. To this end, knowledge is not viewed as not "only residing in the mind of an individual nor in one location but as being distributed across an information network or multiple individuals." (Boitshwarelo, 2011, p.162). The importance of working collaboratively with others by utilising online learning tools cannot be overemphasised.

\section{Use of learning management systems}

Turnbull, Chugh and Luck (2020 p 1) define learning management systems as "online learning technologies for the creation, management, and delivery of course material." A learning management system performs a number of tasks in managing students' learning. Juhary (2014, p. 23) notes that a digital learning platform "can be a singularly critical platform to report on students' learning progress and to monitor students' learning engagement". The view of managing learning through a digital learning platform is shared by Dalsgaard (2006) who observes that such a learning platform allows course instructors to integrate the different elements of the teaching and learning process. One of the functions of a learning management system is that it provides for course instructors' to organise and manage content (Martin-Blas \& Serrano-Fernandez, 2009).

A learning management system supports students' learning. In line with the Connectivism learning theory, the student is connected to the learning material, the fellow learners, and course instructors through an LMS. Learning in a networked environment promotes student-centredness and "promotes inquiry-based learning and digital literacy, empowers the learning, and offers flexibility as new technologies emerge" (Drexler, 2010, p.371). Furthermore, an LMS creates learning environments where learners can regulate and pace their learning. This allows learners to take control of their learning.

Apart from the delivery of content, a learning management system is useful in the administration of the learning process (Sallum, 2008). The course instructors are able to make learning content accessible and manageable to students. Other processes such as student registration, communication, testing, scheduling, student tracking, monitoring are possible through a learning management system (Cavus, 2013). Cavus and Alhih (2014, p.520) note that the LMS "manages, tracks and reports on the interaction between the learner and the content and the learner and the instructor." It is clear from the foregoing view that the course instructor is able to manage the process of teaching and learning and be in charge of the processes.

\section{Advantages of online learning}

Kattoua, Al-Lozi and Alrowwad (2016) studied E-Learning Systems in Higher Education and identified some advantages and disadvantages of e-learning. They state that online learning is less expensive to deliver, affordable and saves time.These advantages of e-learning have been echoed by other researchers. Muruthy and Yamin (2017) argue that e-learning spares the cost, time and space in the learning process and in that way is beneficial to the online users. 
Kattoua et al. (2016) also assert that online learning allows students to access the materials from anywhere at any time and access global resources and materials that meet their level of knowledge and interest. There is also selfpacing for slow or quick learners, which reduces stress and increases satisfaction and retention. In other words, online learning offers flexibility. Dumford and Miller (2018), however, argue that while online education has the potential to reach a wider audience, the unique needs and situations of these students can greatly impact their educational experiences. According to them, students' different background characteristics influence their preference for an online course format and their success or otherwise in any academic setting. Hence, Dumford and Miller (2018) caution that institutions of learning should be careful not to aggravate existing gaps among students.

Other advantages of e-learning cited by Kattoua et al. (2016) are that E-learning allows more effective interaction between the learners and their instructors. Learners can track their progress using emails, discussion boards and chat room. Learners can also learn through a variety of activities that apply to many different learning styles that learners have, it helps the learners develop knowledge of using the latest technologies and the Internet, and it could improve the quality of teaching and learning as it supports the face-to-face teaching approaches. The interactions provided by e-learning through discussion boards and chat rooms can be explored for effective student collaboration and building of communities of learning.Chen, deNoyelles, Patton, and Zydney (2017, p.165) explain that asynchronous discussions in online learning "provide a space for instructors and students to form a community, to engage in dialogue about the course content, and to co-construct knowledge". In asynchronous discussions, students have sufficient time to think before responding, form new knowledge and ideas through writing, and due to the nature of discussion forums students can always return to their original contributions, promoting reflection and self-assessment.

\subsection{Disadvantages of online learning}

Despite the aforementioned pros of online learning some disadvantages have been identified. Online students may have feelings of isolations as there is little or no "in-person" contact with the faculty member (Kattoua et al., 2016). Wijekumar et al. (2006) as cited in Dumford and Miller (2018) share the similar view about isolation in online learning. They posit that online learners may feel isolated from their course instructors if traditional assessments like multiple-choice quizzes and exams are used too heavily. Dumford and Miller (2018) further highlight issues of cheating and overreliance on the summative feedback from graded quizzes and exams which might limit the formative feedback given to students during the learning process.

Some problems are technical in the sense that students might experience a difficult learning curve in how to navigate within the system and problems with the technology (Kattoua et al., 2016). These authors added that there were also some disadvantages that seemed to be common in developing countries such as lack of funds to purchase new technology, lack of adequate e-learning strategies, training for staff members and most importantly the learner resistance to using the e-learning systems. Similar findings were reported by Mthethwa-Kunene and Maphosa (2020) that ODL students' utilisation of a Learning Management System was hindered by institutional factors such as inadequate technological infrastructure, insufficient student training and support, and limited usage of the utilisation of the LMS by course instructors. These factors limit students' interactions on the LMS and formation of effective communities of learning.

Kattoua, Al-Lozi and Alrowwad (2016) also highlighted that there was also learners' dissatisfaction in using elearning which included lack of a firm framework to encourage learners to learn, a high level of self-discipline or self-direction is required. Learners with low motivation or bad study habits may fall behind, absence of a learning atmosphere in e-learning systems, the distance-learning format minimizes the level of contact, e-learning lacks interpersonal and direct interaction among learners and teachers, and when compared to the face-to-face learning, the learning process is less efficient. Similarly, in order to be successful in online learning, students may need additional motivation, organization, and self-discipline (Dumford \& Miller, 2018). Dumford and Miller (2018, p. 462) concluded that "If a primary goal of online learning is to reach a wider range of students and provide educational opportunities for those who might not otherwise have such access, then it is important to ensure that online education students are partaking in equally engaging educational experiences that contribute to their learning and success". 


\section{Unpacking community of inquiry framework}

Garrison, Anderson and Archer (2000) developed the "community of inquiry" (COI) model for online learning environments. They described an educational community of inquiry as a group of people who work collaboratively, engaged in purposeful critical discourse and reflection to construct personal meaning, and confirm mutual understanding. An educational community of inquiry is defined as "a group of individuals who collaboratively engage in purposeful critical discourse and reflection to construct personal meaning and confirm mutual understanding" (Garrison, 2011, p.2). According to Garrison (2009), the Community of Inquiry theoretical framework represents a process of creating a deep and meaningful (collaborative-constructivist) learning experience through the development of three interdependent elements - social, cognitive, and teaching presence (Garrison, 2009).

The community of inquiry has become one of the more popular models for online and blended courses that are designed to be highly interactive among learners and faculty using discussion boards, blogs, wikis, and videoconferencing. The COI model advocates for social, teaching, and cognitive learning. Social presence is "the ability of participants to identify with the community (e.g., course of study), communicate purposefully in a trusting environment, and develop interpersonal relationships by way of protecting their individual personalities." (Garrison, 2009). Teaching Presence is the design, facilitation, and direction of cognitive and social processes for realizing personally meaningful and educationally worthwhile learning outcomes (Anderson, Rourke, Garrison, \& Archer, 2001). Cognitive Presence is the extent to which learners are able to construct and confirm meaning through sustained reflection and discourse (Garrison, Anderson, \& Archer, 2001).

The CoI framework postulates that teaching presence, social presence and cognitive presence are interrelated and work constantly changing ways throughout the educational experience (Nolan-Grant, 2019). Common issues in online learning such as limited interactivity may result in failure to enable a true Community of Inquiry. NolanGrant (2019) used a postgraduate online module to demonstrate how the CoI framework can be employed to address issues of engagement. That is, using $\mathrm{CoI}$ as a learning design model can mitigate engagement challenges.

\section{Ways on promoting social presence on the Moodle LMS}

Moodle is an example of LMS that shows how technology could facilitate components of the CoI framework for distance learners. Moodle as a teaching platform (Thomas, Herbert \& Teras, 2014) brings out features that support social presence. The Moodle forum is used to encourage student to student as well as student to instructor interaction. In order to encourage social presence instructors can create a common room (Richardson, Ice, \& Swan, 2016) forum on the general section on their Moodle course page. The forum is used to introduce instructors to students and students to introduce themselves to one another. Other discussion forums can be created around meaningful and stimulating questions.

In order to establish an online community of trust on the LMS, instructors develop initial course activities such as ice breakers (Fiock, 2020, p.141). The Moodle chat activity can be used to introduce an ice-breaker such as a word game. Richardson et al.(2016) point out that instructors using the Moodle discussion forum, can require learners to respond to their peers' postings or to respond to their own postings. They further state that students serve as experts when they are leading discussions thus making their presence as well. Another action step that promotes social presence is the grading of forums (Richardson et al., 2009). Moodle forum sum of rating makes participation in discussion a significant part of course grades .However, facilitating the forums comes with its own inherent challenges. It is worth noting that training and general awareness of the challenges can make forums a successful pedagogy technique.

Instructors could also consider incorporating Moodle wiki in their course activities. Wheeler, Yeomans, and Wheeler (2008, p.989) suggested that wikis enable students to collaboratively generate, mix, edit, and synthesize subject-specific knowledge within a shared and openly accessible digital space. Such activities are known (Peacock \& Cowan, 2016) to enhance learners' social presence in an online learning environment. Joyce and Brown (2009) pointed out that wikis allow learners to co-construct knowledge but at the same time remediating isolation particularly, in distance learning. To add on, the Moodle journal is another activity that promotes social presence. Richardson et al., (2016) claim that learner to instructor interaction is enhanced on an individual basis. Nevertheless, wikis and journals should be used purposefully, instructors are encouraged to use the tools to give 
meaningful assignments to learners.

Dunlap and Lowenthal (2018) noted that learners may post video responses, using apps like screencasting. From that perspective, Moodle HTML editor provides features that allow incorporating video within the course content. Furthermore, Moodle can be integrated with third-party applications. Learners and instructors can create multimedia resources outside Moodle then upload using the Sharable Content Object Reference Model (SCORM) and IMS content packages. Pi, Hong and Yang (2017, p.347) highlighted the importance of nonverbal and relational cues in online learning (e.g. an instructor's image). Including an instructor's video enhances the social presence and achievement of learning outcomes.

\section{Ways on promoting cognitive presence on the Moodle LMS}

Enhancing cognitive presence can be done by allowing students to interact with sharing ideas. Moodle facilitates the sharing through the discussion forum, wiki, and journal (Peacock \& Cowan,2016; Stewart, 2017). Moderating forums is an important strategy of supporting cognitive presence. However, it is important to note that the interaction among students does not automatically translate to meaningful knowledge construction.

Cognitive presence can be modeled using Moodle groups. Learners can discuss, brainstorm, and reflect collectively (Dunlap et al., 2016). Group tasks allow students to drill down on a topic of interest, providing opportunities for integration with previous knowledge. These group activities often lead learners to become critical thinkers. While Moodle supports groups it should be noted that as size increases, teamwork becomes more complex. Akcaoglu \& Lee (2016) explains that the complexity is caused by the increased number of individuals in a group which may also impact group member's attention negatively. Therefore, the instructors are encouraged to play the facilitation role and implement strategies such as weaving and summarising discussions. Learners may also assist in the process.

Dunlap and Lowenthal (2018) articulate a view on promoting cognitive presence suggesting that learners should be given space to create and post resources. Moodle allows adding files in the activities. This necessitates learners to independently share resources related to concepts discussed in class. Furthermore, instructors should build opportunities for students to think and apply the course content together. Moodle wikis can be used to allow learners collaborate and create content.

Another perspective discussed by Richardson et al. (2009) is developing grading rubrics for discussion and assignments that reward desired cognitive behaviors. The authors further suggest that learners are to develop rubrics. The focus is to help students understand and apply new concepts. Furthermore, the use self-testing, practice assignments, simulations, and other interactive activities to support skill development and convergent thinking (Richardson et al., 2009). Moodle quiz supports ungraded assessments.

\section{Ways on promoting teaching presence on the Moodle LMS}

Preisman (2014) suggests that one of the roles that instructors play in creating a teaching presence is designing and organizing of the learning experience. This should be done before the course begins and during the run of the course.Teaching presence is enhanced by personalising the Moodle course page for example choosing a different format for your Moodle site. To add on, video introductions help learners connect to the instructor and let them know there is a real person behind the course. A video introduction and tour of a Moodle course should be availed to assist learners with navigating the course.

Second, instructors are responsible for creating and monitoring activities that stimulate interaction between the learners, instructors, and content resources (Preisman, 2014). The Moodle LMS allows for regular communication which aids the instructor to build a strong teacher presence within a Moodle course. Giving feedback on assignments is a critical part of the direct instruction component of teaching presence. Moodle assignment activity has a "remind me to grade by" setting .Once the setting is enabled a reminder is sent to the instructor so they can grade and provide feedback in real-time. Feedback on Moodle can be provided in several ways that include Moodle HTML editor or via an Inbox message and group feedback using the group announcement or discussion forum. The announcements forum can be used to send normal email updates to help learners to remember due dates. 
Finally, Preisman (2014) suggests that instructors must contribute to academic knowledge and relevant experiences through forms of direct instruction. Anderson (2004) also notes that students contribute as well because they bring their own knowledge and experience to the course. Instructors may provide students' views and comments in Moodle forum conversations (Stewart, 2017). Design learning experiences that address all learning styles need to be considered (Dunlap \& Lowenthal, 2018; Stephens \& Roberts, 2017).Instead of just posting lecture notes, instructors may use audio or video for posting week after week lectures narrated presentation.

Dunlap and Lowenthal (2018) suggested that to increase teaching presence, universal design for learning (UDL) principles must be addressed in all created materials. Narrated slides customize the learning experience for learners and create a feeling of association with the instructor. Within the narrated slides, the instructor can review assessments and demonstrate the solutions for question items. Though the narrated slides require a lot of effort to make, they can be archived and used for a few semesters without being edited.

\section{Conclusions}

It is clear from the foregoing discussion that online learning platforms should be utilised to enhance collaborative learning experiences for the learners. Course instructors would be required to understand the features of a learning management system and plan for the creation of communities of inquiry. There is a need for deliberate plans on the implementation of opportunities for collaborative learning online.

\section{Recommendations}

In the light of the foregoing discussion, we make the following recommendations;

a) Course design for online learning programmes should provide for opportunities for high learner interactivity with content, course instructors and fellow learners.

b) Features of a digital learning platform should be studied carefully and features that assist students to work collaboratively should be optimised.

c) Course instructors should undergo periodic online pedagogical training in order to understand and appreciate the role of online pedagogies in influencing selection and use of relevant technologies to foster collaborative learning.

d) The Moodle LMS as an open source software is accessible and affordable as a learning platform and course instructors should maximise the use of its functions to promote online collaborative learning.

e) All the presences as advanced by the Communities of Inquiry theory namely the cognitive, teaching and social presences should be promoted in different ways by utilising the Moodle LMS where it is used as the preferred digital learning platform.

f) Course instructors should promote high-level interactivity in online learning in order to offer learners very rich learning experiences by utilising the available technologies.

\section{References}

Akcaoglu, M., \& Lee, E. (2016). Increasing social presence in online learning through small group discussions. The international review of research in open and distributed learning, 17(3).

Anderson, T. (2017). How communities of inquiry drive teaching and learning in the digital age. Online Learning Apprentissage en ligne. Contact North/Contact Nord. www.contactnorth.ca

Boitshwarelo, B. (2011). Proposing an Integrated Research Framework for Connectivism: Utilising Theoretical Synergies. International Review of Research in Open and Distance Learning, 12 (3), 161 - 179

Cavus, N. (2013). Selecting an learning management system (LMS) in developing countries: instructors' evaluation. Interactive Learning Environments, 21(5), 419-437.

Cavus, N. \& Alhih, M. S. (2014). Learning management systems use in science education. Procedia Social and Behavioral Sciences, 143, 517 - 520

Chen, B., deNoyelles, A., Patton, K., \& Zydney, J. (2017). Creating a community of inquiry in large-enrollment online courses: An exploratory study on the effect of protocols within online discussions. Online Learning, 21(1), 165-188. Doi: 10.24059/ olj.v21i1.816 
Dalsgaard, C. (2006). Social software: E-learning beyond learning management systems. European Journal of Open Distance and e-Learning, 2.

Drexler, W. (2010). The networked student model for construction of personal learning environments: Balancing teacher control and student autonomy. Australasian Journal of Educational Technology, 26(3). https://doi.org/10.14742/ajet.1081

Dumford, A. D., \& Miller, A. L. (2018). Online learning in higher education: exploring advantages and disadvantages for engagement. J Comput High Educ, 30, 452-465. https://doi.org/10.1007/s12528-018$\underline{9179-\mathrm{Z}}$

Espasa, A., \& Meneses, J. (2010). Analyzing feedback processes in an online teaching and learning environment: An exploratory study. Higher Education, 59(3), 277-292.

Fiock, H. (2020). Designing a community of inquiry in online courses. The International Review of Research in Open and Distributed Learning, 21(1), 135-153.

Garrison, D. R. (2011). E-Learning in the 21st Century: A Framework for Research and Practice (2nd Ed.). London: Routledge/Taylor and Francis.

Harasim, L. (2017). Learning theory and online technologies. Second Edition. New York: Routledge.

Joyce, K. M., \& Brown, A. (2009). Enhancing social presence in online learning: Mediation strategies applied to social networking tools. Online Journal of Distance Learning Administration, 12(4).Retrieved 07

September 2020 from https:/www.westga.edu/ distance/ojdla/winter124/joyce124.html

Juhary, J. (2014). Perceived Usefulness and Ease of Use of the Learning Management System as a Learning Tool. International Education Studies, 7(8), 23-34.

Kattoua, T., Al-Lozi, M., \& Alrowwad, A. (2016). A review of literature on E-learning systems in Higher Education. International Journal of Business Management and Economic Research (IJBMER), Vol 7(5), pp. 754-762 Available at: www.ijbmer.com 754

Larson, P. D. (2002). Interactivity in an electronically delivered marketing course. Journal of Education for Business, 77(5), 265-269.

Martin-Blas, T., \& Serrano-Fernandez, A. (2009). The Role of New Technologies in the Learning Process: Moodle as a Teaching Tool in Physics. Computers and Education, 52, 35-44.

MacKinnon, G. R. (2002). Practical advice for first time online instructors: A qualitative study. Journal of Instruction Delivery Systems, 16(1), 21-25.

Mthethwa-Kunene, K.E. \& Maphosa, C. (2020). An Analysis of Factors Affecting Utilisation of Moodle Learning Management System by Open and Distance Learning Students at the University of Eswatini, American Journal of Social Sciences and Humanities 5 (1), 17-32,

Muruthy, A. E., \& Yamin, F. M. (2017). The Perception and Effectiveness of Learning Management System (LMS) Usage among the Higher Education Students. Journal of Technology and Operations Management, $12(1), 86-98$.

Nolan-Grant C. R. (2019). The Community of Inquiry framework as learning design model: a case study in postgraduate online education. Research in Online Technology, 27, pp.1-15

Pi, Z., Hong, J., \& Yang, J. (2017). Does instructor's image size in video lectures affect learning outcomes? Journal of Computer Assisted Learning, 33(4), 347-354.

Peacock, S., \& Cowan, J. (2016). From presences to linked influences within communities of inquiry.International Review of Research in Open and Distributed Learning, 17(5), 267-283.

Preisman, K. A. (2014). Teaching Presence in Online Education: From the Instructor's Point of View. Online Learning, 18(3), n3.

Richardson, J., Swan, K., Lowenthal, P., \& Ice, P. (2016, April). Social presence in online learning: Past, present, and future. In Global Learn (pp. 477-483). Association for the Advancement of Computing in Education (AACE).

Sallum, S. A. (2008). Learning management system implementation: building strategic change. Retrieved 01 September 2020 from http://findarticles.com/p/articles/mi_hb5835/is_200801/ai_n32281677/?tag=content;col1

Salmon, G. (2013). E-tivities: The key to active online learning. London: Routledge.

Siemens, G. (2005). Connectivism: Learning as network creation. e-Learning Space.org website. http://www.elearnspace.org/Articles/networks.htm. Accessed 20 September 2020

Thomas, L., Herbert, J., \& Teras, M. (2014). A sense of belonging to enhance, participation, success and retention in online programs. The International Journal of the First Year in Higher Education, 5(2), 69-80. 
Turnbull, D., Chugh, R. \& Luck, J. (2020). Learning management systems: a review of the research methodology literature in Australia and China. International Journal of Research \& Method in Education.https://doi.org/10.1080/1743727X.2020.1737002 